\title{
Hyperbole and emotionalisation: Escalation of pragmatic effects of proverb and metaphor in the "Brexit" debate
}

\author{
Andreas MUSOLFF \\ University of East Anglia \\ Norwich, UK
}

\begin{abstract}
(How) Can the use of hyperbole in metaphorical idioms and scenarios contribute to an increase in emotionalisation of public debates? Using a research corpus of quotations from British politicians' speeches and interviews and of press texts 2016-2020, this paper investigates hyperbolic formulations in Brexit-related applications of the proverb 'You cannot have your cake and eat it' and related scenarios of national liberation, which appear to have strongly boosted emotionalised public debates. For instance, Brexit proponents' reversal of the cake proverb into the assertion, 'We can have our cake and eat it', and their figurative interpretation of Brexit as a war of liberation (against the EU) triggered highly emotional reactions: triumphant affirmation among followers, fear and resentment among opponents. The paper argues that the combination of figurative speech (proverb, metaphor) with hyperbole heightened the emotional and polemical impact of the proBrexit argument. Whilst this effect may be deemed to have been rhetorically successful in the short term (e.g. in referendum and election campaigns), its long-term effect on political discourse is more ambivalent, for it leads to a polarisation and radicalisation of political discourse in Britain (as evidenced, for instance, in the massive use of hyperbole in COVID-19 debates). The study of hyperbole as a means of emotionalisation thus seems most promising as part of a discourse-historical investigation of socio-pragmatic effects of figurative (mainly, metaphorical) language use, rather than as an isolated, one-off rhetorical phenomenon.
\end{abstract}

Keywords: emotionalisation, hyperbole, metaphor, proverb, scenario

For citation:

Musolff, Andreas. 2021. Hyperbole and emotionalisation - escalation of pragmatic effects of metaphor and proverb in the Brexit debate. Russian Journal of Linguistics 25 (3). 628-644. https://doi.org/10.22363/2687-0088-2021-25-3-628-644

Научная статья

\section{Гипербола и эмоционализация: усиление прагматических эффектов пословиц и метафор в дебатах о Брексите}

\author{
Андреас МУЗОЛФ
}

Университет Восточной Англии

Норидж, Великобритания

\section{Аннотация}

В данной статье ставится вопрос - может ли использование гиперболы в метафорических идиомах и сценариях способствовать эмоционализации публичных дебатов, а если да, то как. В контексте Брексита исследуются гиперболические высказывания с использованием 
поговорки You cannot have your cake and eat it и связанные с ней сценарии национального освобождения, которые вызвали эмоциональные публичные дебаты. Например, сторонники Брексита превратили данную поговорку в утверждение We can have our cake and eat it, а их образная интерпретация Брексита как освободительной войны (против ЕС) вызвала сильную эмоциональную реакцию: у последователей Брексита - эмоциональную поддержку, у их оппонентов - страх и негодование. Материал для исследования извлекался из корпуса цитат, использованных в выступлениях британскими политиками, а также из интервью и газетных текстов (2016-2020 гг.). В статье показано, что сочетание фигур речи (пословиц, метафор) с гиперболой усиливает эмоциональное и полемическое воздействие на аудиторию. Хотя этот эффект можно считать риторически успешным в краткосрочной перспективе (например, в ходе референдума и избирательных кампаний), его долгосрочное влияние на политический дискурс более амбивалентно, поскольку оно ведет к поляризации и радикализации политического дискурса в Великобритании (о чем свидетельствует, например, широкое использование гипербол в дебатах о COVID-19). Таким образом, наиболее перспективным представляется изучение гиперболы как средства эмоционализации в парадигме дискурсивно-исторического исследования социально-прагматических эффектов образного (в основном, метафорического) использования языка, а не как изолированного, единичного риторического средства.

Ключевые слова: эмоциональность, гипербола, метафора, пословица, сценарий

\section{Для цитирования:}

Musolff A. Hyperbole and emotionalisation - escalation of pragmatic effects of metaphor and proverb in the Brexit debate. Russian Journal of Linguistics. 2021. Vol. 25. № 3. P. 628-644. https://doi.org/10.22363/2687-0088-2021-25-3-628-644

\section{Introduction}

The concept of emotionalisation implies a heightening of emotional intensity, as defined in psychology and also in an approach to linguistics that is interested in the "emotive" and "interpersonal" aspects of language (Alba-Juez \& Larina 2018, Jakobson 1960, Halliday 1978, Mackenzie \& Alba-Juez 2019). It presupposes a basic 'given-ness' of emotions in discourse and focuses on their escalation to a higher degree of outspoken-ness and/or crassness, perhaps even reaching the realm of taboo (Allan \& Burridge 2009, Bednarek 2019). Political discourse provides many examples of such emotionalisation, because its contents are usually controversial and because its participants, e.g. politicians and media, compete for attention and approval from, the public and have an interest in surpassing each other in expressing emotionally charged attitudes towards and judgements about the respective topics. A high degree of emotional intensity is thus a characteristic of public polemic but it can always be ratcheted up even further. Its analysis thus entails an explanation of how a given emotional aspect of language use is further escalated.

In this article I will investigate the role of hyperbole in emotionalising communication in politics. Since Antiquity hyperbole has been well-known and studied as a rhetorical trope (Lanham 1991: 86, Lausberg 1984: 74, 138) - even Aristotle (2000: 3.11.16) connected hyperbole with the passions and passionate speech. More recently, hyperbole has become the object of research in several branches of linguistics, specifically Pragmatics including Relevance Theory (Carston \& Wearing 2011, 2015, Norrick 2004), Cognitive Studies, especially regarding the interplay with metaphor and irony (Barnden 2017, 2018, 2020, 
Burgers, Brugman, Renardel de Lavalette \& Steen 2016, Burgers, Renardel de Lavalette \& Steen 2018, Colston \& Keller 1998, Peña \& Ruiz de Mendoza 2017) and political discourse studies (Kalkhoven \& De Landtsheer 2016). They have emphasised the scalar and evaluative character of hyperbole and have noted its frequent usage in polemic and emotive discourse. Here we take a corpus-based view at the relationship of hyperbole and metaphor, specifically their combination in political discourse, both in the short term but also in a medium-term discoursehistorical perspective (Reisigl \& Wodak 2009).

Based on a research corpus drawn from politicians' speeches and interviews and press texts dealing with Britain's withdrawal from the European Union ("Brexit") from 2016 to 2020, the paper investigates the role of hyperbolic metaphors. Our central example are hyperbolic applications of the proverb 'You cannot eat your cake and have it (too)', which together with further hyperbolic metaphors helped to heighten the emotional and polemical impact of the pro-Brexit argument. Whilst this effect may be deemed rhetorically successful in the short term (insofar as pro-Brexit-hyperbole facilitated victory in 2016 referendum and Johnson's electoral victory in 2019), its long-term effect on political discourse in Britain is ambivalent. Its boost for the emotionalisation of public discourse precipitated a general polarisation and radicalisation of the political public, which can also be witnessed in the debate about the COVID-19 pandemic.

\section{Brexit, emotions and metaphor}

Over the past five years, the public debates in the United Kingdom (UK) about Britain's withdrawal from the (EU), which was officially completed in January 2020 have been a prominent site for emotionalised political debates Britain (Buckledee 2018, Koller, Kopf \& Miglbauer 2019, Charteris-Black 2019, Oliver 2018). An early climax of that debate was reached in June 2016 when, after about four months of intensive (and several years of preparatory) campaigning for Brexit by "Eurosceptics", a 51.9\% majority of the UK electorate voted in favour of withdrawal. The most prominent emotions connected with the Eurosceptic motivation for Brexit were ANGER, e.g. about a perceived unfair financial and administrative burden on Britain imposed by the EU, FEAR, e.g. of growing mass immigration from other EU countries, and PRIDE, e.g. in Britain's national sovereignty and its history as an independent nation state (Rowinski 2017, Spiering 2015). During the referendum campaign, Brexit opponents expressed and propagated their emotions, too, e.g. FEAR of their nation losing allies in the EU and, with them, economic and political clout internationally, but they were beaten back by pro-Brexit voices who denounced such emotions as .being deliberately invented, e.g. through the dysphemistic label "Project Fear" (Payne 2016, Pesendorfer 2020).

Metaphors have played a key role in expressing both the afore-mentioned basic emotions triggered by Brexit, as well as the more complex, mediated reactions during the different phases of the public debate as it unfolded between 2016 and 
2020 (Charteris-Black 2019, Dallison 2017a, b, Đurović \& Silaški 2018, Musolff $2017,2019)$. This is no surprise as figurative language is a fundamental characteristic of political communication (Lakoff 1996, Lakoff \& Johnson 1980/2003, Musolff 2016). But the frequency, intensity and complexity of Brexitmetaphorisations was so pervasive that it led to the emergence of a special "Metaphor Brexicon" (Charteris-Black 2019: 323) as part of the Brexit-jargon, many of whose terms and allusions are comprehensible only to insiders of the British media "community of practice" (Holmes \& Meyerhoff 1999). Consider the following headlines:

(1) Why shouldn't we try to have our Brexit cake and eat it too? (The Daily Telegraph, 29/11/2016)

(2) Brexit weekly briefing: cake off the menu as hard choices loom. (The Guardian, 04/07/2017)

(3) The delusions of cakeism (The New European, 15/09/2017)

(4) Rosbif [sic] with cake. What Europe thinks of Boris Johnson (The Economist, 22/06/2019)

Without further contextualisation, these headlines are enigmatic: at best, readers can make out that Brexit is viewed, strangely enough, as a "cake", that there is an ideology based on it ("cakeism", comparable to other "isms") and that a weird combination of "rosbif" (a supposed mock-European loan of English roast beef) with cake is associated with Boris Johnson, the British Prime Minister at the time of writing and the leading pro-Brexit-campaigner from February 2016 onwards. ${ }^{1}$ If they have a good knowledge of English idioms they may recognise the allusion to the proverb, You cannot have your cake and eat it (too) in (1), ${ }^{2}$ but its usage in that example is problematic because it asks a seemingly senseless question: if common sense - as embodied in the proverb - states that 'eating a cake' and also 'having it' (in the archaic sense of keeping it) is impossible and/ or unjustifiable, ${ }^{3}$ why suggest that it is worth trying?

In the following section we focus on applications of this proverb as an example of how a combination of metaphor and hyperbole can trigger the intensification of emotional reactions and lead to a polarisation and radicalisation of public debate. The sample of applications of the haveleat cake proverb includes 208 instances of the phrase and amounts to 139,396 word tokens; it is drawn from print and online versions of Daily Express, Daily Mail, Daily Mirror, Financial Times, Marxism

${ }^{1}$ See e.g. The Daily Telegraph, 21 February 2016: "Boris Johnson backs Brexit as he hails 'once-in-a-lifetime opportunity' to vote to leave EU'.

${ }^{2}$ For present-day usage of the proverb and its history dating back to the mid-16 $6^{\text {th }}$ century see Ayto 2010: 53; Brewer's Dictionary of Phrase \& Fable 2001: 189, Shorter Oxford English Dictionary 1993, vol. 1: 317; Speake 2015: 147-148; Wilkinson 2008: 47.

${ }^{3}$ The Daily Telegraph, for instance, usually applies the proverb in its standard version, e.g. in a headline from 2014, "The whining rich can't have their cake and eat it", which denounced as hypocritical the attitude of those who "monopolise wealth in the 21 st Century [and still] moan about taxes" (The Daily Telegraph, 11/08/2014). 
Today, New Statesman, The Daily Telegraph, The Economist, The Guardian/Observer, The Independent, The National, The New European, The Scotsman, The Spectator, The Street, The Sun, The Times/Sunday Times, The Yorkshire Post. ${ }^{4}$ we first give an overview of the "discourse career" of the cakeBrexit metaphor and subsequently analyse its emotionalisation effect before contextualising it later on in the wider perspective of Brexit-hyperbole.

\section{Proverb and hyperbole}

The application of a special version of the proverb, You cannot have your cake and eat it, to Brexit by Boris Johnson was originally a self-quotation. Back in 2009, i.e. long before Brexit but when he was already the Mayor of London, Johnson characterised his political ambitions by way of a metaphor that alluded to the well-known proverb in an interview:

(5) "Let's not beat about the bush here. My policy on cake is still pro having it and pro eating it." (The Daily Telegraph, 10/04/2009)

Johnson's interview answer can be interpreted as a (mildly) self-ironical confirmation that his political ambitions were extremely high but their achievability was uncertain. ${ }^{5}$ In order to avoid being seen as over-ambitious, he played with the standard 'impossibility/ absurdity' sense of the proverb but also indicated a determination to 'try the impossible'. It had a hyperbolic element that added a humorous aspect and ambiguity: ${ }^{6}$ strictly speaking, having/keeping a cake and eating the same cake is impossible. Thus, Johnson presented a goal that he intended to as an 'impossibility' - while it was not absolutely impossible after all to achieve (as we know with hindsight, given his rise to power as the UK's Prime Minister within a decade). This internal contradiction makes his statement quasiparadoxical: Johnson used the extreme end of the scale of ambition as a benchmark instead of the more plausible but less exciting notion of achieving a specific, limited goal (which would have equalled eating the cake but not keeping it). His formulation fulfilled the basic condition of hyperbolic language use as "an expression that is more extreme than justified given its ontological referent" (Burgers, Brugman, Renardel de Lavalette \& Steen 2016: 166). Its “extreme" aspect

\footnotetext{
${ }^{4}$ This database is part of a larger research corpus ("EUROMETA") of figurative language use in British and German debates about European Union politics (Musolff 2016: 14-15).

${ }^{5}$ Within the largely sympathetic article in the Daily Telegraph, the proverb-application was embedded in a passage where Johnson was described as "is a Merry England Tory, who stands for a generous conservatism in which cakes and ale are never willingly sacrificed on the altar of some desiccated doctrine" (The Daily Telegraph, 10/04/2009). Johnson himself has written regularly for the Daily Telegraph since the mid-1990s (Gimson 2006, 90-102; Purnell 2011: 106-126),

${ }^{6}$ Ambiguity, hyperbole as well as exaggerated understatement are among Johnson's favourite rhetorical techniques. In the same year as that of the Daily Telegraph interview he described himself as a "mere Mayor of London, as a mere toenail in the body politic" (BBC Newsnight, 05/10/2009), thus achieving at the same time an ostentatious self-denigration (as a lowly 'toenail') and its selfreferential disclaimer (by pointing to his position as Mayor of the nation's capital).
} 
lay in the degree of qualitative exaggeration, which is one of the main types of hyperbole: something that is in fact not viewed by the speaker as being completely unachievable is presented as if it were (Colston \& O'Brien 2000, Norrick 2004).

Seven years later Johnson applied this proverb version to announce his Brexitambitions in as positive a light as possible to the right-wing tabloid The Sun. By this time, he had become Foreign Secretary in the Conservative government under Prime Minister Theresa May, which had emerged after the 2016 Brexit-referendum:

(6) 'We'll have our cake and eat it'. BORIS Johnson has declared his support for a hard Brexit [...]. He also insisted we will get immigration controls back as well as continuing open trade with the EU. Mr Johnson told The Sun: "Our policy is having our cake and eating it. We are Pro-secco but by no means anti-pasto". (The Sun, 30/09/2016)

The pun on Italian culinary products in the last sentence showed that Johnson still tried to appear witty and jovial, but his proverb-application was no longer meant as an ironic "echo" (Wilson \& Sperber 2012) of the standard (negated) proverb, but rather as an emphatic (non-standard) assertion applied to UK policy towards the EU. Johnson's policy promise of having the cake and eating it openly announced that the UK government tried to achieve two objectives that were often seen as excluding each other, i.e. maintaining on the one hand full "immigration controls" and on the other hand "open trade". The EU's "internal market" system, however, implied that the free movement of people (i.e. migration from one EU country to another) and free trade were interdependent; Johnson's aim of keeping freedom of trade for the UK whilst ditching freedom of movement was therefore an implicit challenge to the EU's regulations. Unlike his 2009 usage, Johnson's announcement of combining both goals was intended to be received as a reassuring promise that the British government would try to achieve maximum benefits from Brexit. Emotionally, it could be linked to FEAR (or at least UNEASE) that the final Brexit outcome might turn out to be disadvantageous but also to national PRIDE in Britain being strong enough to negotiate a favourable deal. The promise aimed, unsurprisingly, at reinforcing the Brexit-supporters' feelings of optimism.

This interpretation seems to me more likely than the reading of it as a defensive argument in a "moral dilemma" (Charteris-Black 2019: 3). Brexit - with its onesided ambitions for a maximum, 'win-win' outcome for the British side may have been a moral dilemma for its opponents but these were not at all Johnson's (or the Sun's) chief addressees. Johnson's statement in example (6) is a proud, triumphant announcement of following up the promises made before the referendum until a full victory can be declared. Its hyperbole is not tinged by irony; instead, it pronounces the achievability of the impossible as a viable policy and tops it up with jokey wordplay. Of course Johnson was aware of the Brexit-opponents and other critics' derision for his optimism about Britain having its cake and eating it. Such critics could be found across the whole range of media. Thus, the left-wing Guardian and the liberal Economist, but also the pro-conservative Spectator and even the fervently pro-Brexit Daily Express admonished him: 
(7) No Boris, you can't have your Brexit cake and eat it too. (The Guardian, 22/02/2016)

(8) $[\ldots]$ the free having and eating of cake is not an option. (The Economist, 25/06/2016)

(9) Perhaps all will be for the best in this the best of all possible worlds [...] but it is infantile to suppose these [British Brexit goals] will not be countered, or even matched [by the EU]. Other people want cake too. (The Spectator, $02 / 10 / 2016)$

(10) 'Britain can't have its cake and eat it' - Brussels will gang up on UK over

Brexit talks. (Daily Express, 05/10/2016)

Examples (7) and (8) invoke the standard proverb version as the commonsense position (from their standpoint) against Johnson's folly. (9) suggests that if the UK takes an egotistic stance, so will probably "others", i.e. the EU as a whole and/or its various member states. (10) on the other hand insinuates that the others will "gang up" on Britain to not allow its having and eating the Brexit-cake. In (10) Johnson's policy is implicitly endorsed in principle but still viewed as doomed because of the intransigence of the EU as the opposing party. Notwithstanding the varying stances taken in these reactions, all of them demonstrate that by the summer/autumn of 2016 Johnson's can have and eat cake proverb version had already acquired catchphrase status, allowing journalists to use it as an allusion (e.g. "Other people want cake too") on the assumption that their readers were sufficiently familiar with it to recognise its "echo" in ironical references and contradictions. Its popularity even spread to the EU where the then president of the European Council, Donald Tusk, engaged in an elaborate dismissal of what he dubbed Johnson's "cake philosophy":

(11) "The brutal truth is that Brexit will be a loss for all of us, [...] There will be no cakes on the table for anyone. There will be only salt and vinegar." (quoted in The Independent, 13/10/2016)

But whilst Johnson's critics from various quarters took pot shots at his proverb use, his allies in the now Brexit-pursuing government copied his recipe for hyperbolic metaphor. The strongly Brexit-enthusiastic International Trade Secretary Liam Fox was quoted with the prediction that Britain would become

(12) "[...] the world's brightest beacon and champion of open trade" (quoted in Daily Express, 26 September 2016).

Another ally, the new secretary of state appointed for leading the negotiations with the EU, David Davis, bragged that the

(13) "negotiating cards with the EU [were] incredibly stacked in our way." (quoted in The Guardian, 12/10/2016)

In November 2016, Johnson's proverb version was even given an accidental but quasi-official endorsement by May's Cabinet when a Conservative party aide, Julia Dockerill, was photographed carrying notes into the Prime Minister's Office 
which indicated that the government's Brexit preparations were based on Johnson's slogan. It read: "What's the model? Have cake and eat it"' (Daily Mirror, 29/11/2016). Ignoring several dementis by government spokespersons, the British press almost unanimously interpreted the notes as representing the gist of the government's strategy (Musolff 2019: 211-212). The phrase was now also associated with the Prime Minister Theresa May, who was, for instance, reported as "still telling Britons they [could] have their cake and eat it" by "promising barrier-free access to the single market while stopping EU migrants" (The Economist, 01/04/2017).

However, after a national election in June 2017 that deprived the Conservatives of an outright majority in parliament, and with increasing experience of harderthan-expected negotiations with the EU, the government's ostentatious optimism as expressed in Johnson's eat and have cake promise began to weaken. Several newspapers reported that May was recognizing the unfeasibility of retaining all benefits of EU membership without incurring any losses. This change motivated headlines such as,

(14) Britain drops 'have cake and eat it' strategy (The Independent, 02/072017) or

(15) Cake off the menu as hard choices loom (The Guardian, 04/07/2017).

The asserted version of the proverb was now increasingly linked to the goal of a so-called "hard" Brexit that would sever most economic and administrative ties with the EU and incur substantial economic risks. Finance experts in particular, e.g. the Chancellor of the Exchequer, Philipp Hammond, and the Governor of the Bank of England, Mark Carney, urged caution about such a prospect by "discourag[ing] talk of cake" (Hammond, quoted in Daily Mail, 27/06/2017) and denouncing as an illusion the thought that Brexit would be "a gentle stroll or smooth path to a land of cake and consumption" (Carney, quoted in Daily Mail, 20/062017).

However, if Carney and Hammond had intended to bury Johnson's slogan by mocking it, they had not reckoned with the Labour-party under Jeremy Corbyn adopting it in a belated attempt to join in and gain from maximalist Brexit rhetoric. Rebecca Long-Bailey, Labour's shadow business secretary, claimed it for her party:

(16) "We want to have our cake and eat it, as do most parties in Westminster" (quoted in The Guardian, 16/07/2017).

Her statement was, predictably, seized upon as revealing a hypocritical stance of officially opposing the Conservative-led Brexit whilst surreptitiously supporting it for Labour-specific purposes. The Liberal Democrats' spokesman, Tom Brake, commented that Labour's Brexit position was "so indistinguishable from the Conservatives that they have started parroting Boris Johnson" (The Independent, 16 July 2017), and the magazine The Spectator portrayed Long-Bailey ironically as "channel[ing] her inner Boris Johnson" (The Spectator, 16 July 2017). Following the interview, the cake-phrase became a focus for Labour-internal disputes. When their Shadow Chancellor, John McDonnell, suggested that after a change in government Labour would abide by the referendum result but ensure tariff-free 
access to the single market and the customs union, he was accused by the former Labour Prime Minister and Brexit-opponent Tony Blair of caving in to the Conservatives' "having cake and eating it" strategy (The Guardian, 27/11/2017, The New European, 11/12/2017, The Daily Telegraph, 04/01/2018).

With both the largest government and opposition parties each claiming the 'eat-and-have cake' stance for themselves but also disputing it among themselves, the slogan became an easy target for allusive parody by politicians and media commentators who competed to coin new rhetorical niches for themselves to gain the public's attention. Some of the more colourful examples included a warning by Sir Martin Donnelly, a Brexit-critical former civil servant, that leaving the European customs union would be

(17) "like giving up a three-course meal in favour of a packet of crisps" (The Guardian, 27/02/2018);

a description of Brexit plans as a "chimpanzee's tea party Brexit" where there was

(18) cake everywhere. It's been had, it's been eaten, it's been smeared up walls. It's had pots of hot tea smashed over the top of it. It's been scooped on to the end of long hairy fingers and violently jammed into ears.

(The Independent, 08/03/2018)

and an expletive-laden complaint by the Labour MP Alison McGovern describing Brexit as

(19) "the $\mathrm{s}^{* * *}$ cherry on the $\mathrm{s}^{* * *}$ icing on the $\mathrm{s}^{* * *}$ cake that the Tories baked us all in the 1980s." (quoted in Daily Express, 03/03/2018).

The polemical, sarcastic and satirizing drift of these uses, including use of taboo words, bears the hallmarks of hyperbole. Analytically, we can distinguish between two levels of a) proverb-application (in the sense of a propositionally elaborated or allusive use of the can(not) have and eat cake situation and b) its further pragmatic exploitation - through hyperbole - to achieve additional polemical and argumentative, also humorous effects. The new proverb version became a clichéd "scenario" (Musolff 2006) with stereotypical participants (CAKE, EATER), event structure (EATING AND KEEPING) and default evaluative bias ((IM)POSSIBILITY) that served as a 'ground' for rhetorical-pragmatic 'figure'/Gestalt-effects. It is 'mentioned' or echoed rather than 'used' (Sperber \& Wilson 1981), both in the satirical sketches quoted above (see examples 17-19) as well as in the laconic allusions cited earlier in section 2 (see examples 1-4).

\section{Proverb-free hyperbole}

In our sample of overall 208 articles over five years, applications of the Brexitrelated cake-phrase rise from 31 instances in 2016 to 85 instances in 2018 and then fall to under 20 instances in 2020 . The decline may be due to a combination of factors, i.e. the media reaching a 'saturation point' in satirizing the slogan, a realization even on the part of Brexiters that the maximalist negotiation stance 
become obsolete in view of a hardening EU negotiation tactic. Johnson, as Brexit's (and the cake slogan's) chief propagator in public discourse, withdrew from Theresa May's cabinet in June 2018 on account of their disagreement on Brexit strategy, which triggered a Conservative inner-party conflict that led in the end to May's resignation and replacement by Johnson (in July 2019). But whilst the allusions to the eat and have cake proverb became fewer and fewer in public discourse, the hyperbole did not, and certainly not in Johnson's rhetoric. Free to write his column in the Daily Telegraph without having to obey Cabinet discipline, he denounced May's strategy and deal in the starkest terms, no longer invoking a funny proverb version but instead relying on a sinister WAR scenario of 'complete victory or total defeat/ surrender with ensuing enslavement' as the conceptual frame for Brexit:

(20) Victory for Brussels is inevitable. In adopting Chequers, we have gone into battle waving the white flag. (The Daily Telegraph, 03/09/2018)

(21) The EU are treating us with naked contempt - we must abandon this surrender of our country (The Daily Telegraph, 15/10/2018)

(22) The EU will turn us into captives if we sign up to this appalling sell-out of a deal. [...] this 585-page fig-leaf [= May's EU Treaty] does nothing to cover the embarrassment of our total defeat. (The Daily Telegraph, 18/10/2018)

(23) The British people won't be scared into backing a woeful Brexit deal nobody voted for [...]; we now have a cumulative forecast that is downright apocalyptic. (The Daily Telegraph, 06/01/2019)

(24) The people's day of jubilation has been hijacked by spineless pirates. [...] This was meant to be the week of Brexit. And what has happened instead? In one of the most protoplasmic displays of invertebracy since the Precambrian epoch, this Government has decided not to fulfil the mandate of the people. (The Daily Telegraph, 26/03/2019)

(25) Theresa May's plan to enslave us in the customs union with Corbyn's help will never work (The Daily Telegraph, 07/04/2019)

In these examples, a stark opposition is drawn between the 'good' side of (pro-) Brexit Britain and 'evil' forces including both the EU and May's government trying to vanquish, take captive and enslave their victim. ${ }^{7}$ The basic Brexit-related emotions had remained the same since the time of the pro-Brexit campaign: FEAR, ANGER, and (hurt) national PRIDE. However, by spring 2019 they had been rhetorically 'escalated' to an extreme degree and could hardly be topped. In order to keep up his Brexit promise, Johnson had to switch to further extreme rhetorical moves. One of these was to promise a kind of epiphany of a 'maximum gain' Brexit appearing miraculously over the horizon:

${ }^{7}$ Other politicians' and media's Brexit rhetoric during 2019/20 was no less hyperbolic than Johnson's. Both the hard Brexit proponents on the right, i.e. among the Conservatives and the even more radical "UK Independence Party" (later "Brexit Party"), as well as the Labour leadership intent on blockading May's government at any cost (see Charteris-Black 2019: 65-134; Demata 2019; Hansson 2019; Zappettini 2019). 
(26) So don't despair. Don't give up. [Brexit] is going to happen, and at that wonderful moment it will be as though the lights have come on at some raucous party; or as if a turbulent sea has withdrawn to expose the creatures of the shore.... (The Daily Telegraph, 15/04/2019)

In a complementary move he threatened the EU with a violent angry reaction by a Britain likened to the Comic strip figure "Incredible Hulk":

(27) "We'll break free of the EU like the Incredible Hulk. [...] The madder Hulk gets, the stronger Hulk gets" (Daily Mail, 15 September 2019).

Both the renewed 'Brexit-as-paradise' promise and the threat of acting like the "Hulk" were still in line with the hyperbolic scenarios used during the whole Brexit referendum campaign: the win-win vision of a maximum gain through Brexit and its depiction as the only alternative to complete surrender and defeat. However, when "Brexit day" actually came on 31 January 2020 (after several delays), its economic and political impact was nearly zero. Apart from small festivities of Conservative Brexiters in or near their party headquarters there were few emotional reactions and even the Daily Telegraph mainly highlighted the achievement of having passed "three years of bust-ups, backstabbing, tears and turmoil" that had made "the mere act [sic!] of departure" so difficult (The Daily Telegraph $31 / 01 / 2020)$. If the day of Britain officially leaving the EU was a "mere act of departure" even in the eyes of Johnson's most sympathetic media outlet, it certainly was nowhere near a "total victory" or the "wonderful moment" when "lights coming on at a raucous party". On the other hand, it was not a complete defeat or catastrophe for the UK either. So, was Johnson's hyberbolic rhetoric just "much ado about nothing", a mere accompaniment to the political process that had no effect on its outcome?

\section{Preliminary conclusions}

Obviously, the long-term effects of Brexit, their evaluation as success or failure, and their emotional effect are not known yet. There have been voices, mainly on the part of Brexit-opponents, which maintain that the emotionalised rhetoric of the Brexit disputes has led to a deterioration of debating culture and a radicalisation of the public sphere in the United Kingdom (The Guardian, 12/10/2019: “Brexiters' adoption of war language will stop Britain from finding peace", The Observer, 29/09/2019: "Boris Johnson seeks to divide and conquer with his incendiary rhetoric"). Johnson's use of figurative speech is highly deliberate and crafted (Margulies 2019), not a chance product of a specific situation. The coinage of a non-standard version of a proverb, whose canonical form has been entrenched in everyday discourse for four centuries, and the colourful ornamentation of the UK-EU conflict as a battle of a single nation against the threat of enslavement by a contemptuous enemy, evidenced in the examples cited above show that Johnson purposefully presented Brexit as a contest between good and $\mathrm{bad}$, at the end of which could only stand victory or total defeat. The 
psycho-political intention behind this strategy is easy to discern: by portraying Brexit in the most extreme contrasting evaluations, Johnson and his allies tried to raise and mobilise the emotions of their followers to a maximum. The outcomes of the 2016 Brexit referendum with its majority in favour of Brexit, and of the national election in December 2019, which gave Johnson a huge parliamentary majority ( 365 out of 650 seats and a $43.6 \%$ of the vote) seem to vindicate this strategy at least in terms of electoral success. In terms of political strategy, the use of hyperbolic figurative language apparently boosts and 'escalates' the emotional appeal and impact of specific policies, i.e. their connection with positive emotions such as PRIDE and a need to avoid or overcome negative ones (FEAR, ANGER). Acceptance of that connection by recipients in turn boosts voter support for and readiness to actively endorse those policies.

Thus, whilst evidently fit for the purpose of emotionalisation in the short-term, the cake- and liberation war scenarios suffer from an inherent problem that originates in what one might call 'hyperbolic overload'. It is not so much an issue that they are unrealistic and resemble fairy tale and/or comic-story plots but rather that the hyperbolic suggestion of an extremely positive outcome loses its pragmatic value over time and demands an ever more hyperbolic escalation. Like other openly evaluative semantic and pragmatic effects, e.g. euphemism, it is susceptible to a 'treadmill' effect over time (Allen \& Burridge 1991, Pinker 1994, CrespoFernández 2006). The more often and the more emphatically they are used, the less convincing they become. This deterioration seems to be reinforced by an inbuilt comparison of the 'super-positive' intended meaning with perceived 'reality'. The supposed 'positive' politeness of euphemisms such as African American instead of Black American or of passing away instead of dying loses its appeal if experiences of continuing racial discrimination as a social evil or of death as a fearful event expose it as phoney. In the case of hyperbole, which has no intrinsic polarity, it is the exaggeration 'value' itself that diminishes in view of the experiential contrast. If the maximum gain or total victory promised in the pro-Brexit scenarios remains elusive, the suggested extreme result will not come true. The hyperbolic promise becomes a 'hostage to fortune', which is extremely risky in politics, given its unpredictability.

However, it is unlikely Johnson himself will refrain from hyperbolic metaphor use - it seems embedded in his rhetoric. When Britain, like the rest of the world, was facing a new challenge shortly after the low-key event of official Brexit day (31 January 2020), i.e. the outbreak of the COVID-19 pandemic, his pragmaticrhetorical choice was again in favour of optimistic hyperbole in the guise of metaphorical idioms:

(28) "We already have a fantastic NHS, fantastic testing systems and fantastic surveillance of the spread of the disease ... I want to stress that for the vast majority of the people of this country, we should be going about our business as usual." (quoted in The Guardian, 23/03/2020) 
(29) " [...] looking at it all, that we can turn the tide within the next 12 weeks, and I'm absolutely confident that we can send coronavirus packing in this country." (quoted in The Guardian, 23/03/2020)

(30) "We have growing confidence that we will have a test, track and trace operation that will be world-beating and yes, it will be in place by June 1." (quoted in The Guardian, 20/05/2020).

Whilst "fantastic" in (28) may pass as fair, if strong praise, its three-time repetition points in the direction of hyperbole. Turn the tide and send packing in (29) are idiomatic phrases (Ayto 2010: 254, Shorter Oxford English Dictionary 1993, vol. 2: 2066, 3427) that set up a confrontation scenario (UK vs. Coronavirus) with implies superiority (and hence, likely victory) for one side over the other. In (30), the claim to have a world-beating "track and trace" system for people who were infected by the COVID-19 virus in 12 days' time (20 May - 1 June) as part of an inherently competitive scenario of the UK beating the whole world in the field of technology-driven pandemic management was as over-ambitious as Johnson's Brexit promises. Predictably, its trustworthiness was challenged, not just by the political opposition but even by conservative-leaning media, as the experience of its at best limited success made it an easy target for criticism. ${ }^{8}$ Johnson tried to deflect such criticism by accusing his opponents of casting aspersions on the National Health Service and reiterated his world-beating boast (Daily Mail, $03 / 06 / 2020,06 / 08 / 2020$ ), perhaps operating on the assumption that the advantage of employing hyperbolic figurative language as a means to present optimistic messages outweighs the cost of incurring accusations of insincerity. The general appeal of hyperbole for politicians and journalists may lie in its multifunctionality, i.e. the fact that it triggers, answers and escalates multiple basic emotions, e.g. by expressing PRIDE, reassuring FEAR and even seemingly justifying ANGER. As such it seems the trope of choice for achieving political emotionalisation.

(C) Andreas Musolff, 2021
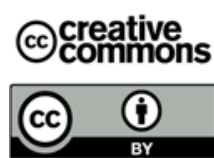

This work is licensed under a Creative Commons Attribution 4.0 International License https://creativecommons.org/licenses/by/4.0/

\section{REFERENCES}

Alba-Juez, Laura \& Tatiana Larina. 2018. Language and Emotion: Discourse-Pragmatic Perspectives. Russian Journal of Linguistics 22 (1). 9-37.

${ }^{8}$ See e.g. The Independent, 05/06/2020: “'Not even virus beating': Government scientific adviser dismisses Boris Johnson's claim test and trace system is world leading"; The Guardian, 17/06/2020: "While other countries are recovering from Covid-19, Britain is still in intensive care"; Daily Mail, 06/08/2020: "Test and Trace is getting WORSE: [...] - but Boris Johnson still insists it's 'world-beating'."' 
Allan, Keith \& Kate Burridge. 1991. Euphemism \& Dysphemism: Language Used as Shield and Weapon. Oxford: Oxford University Press.

Allan, Keith \& Kate Burridge. 2009. Forbidden Words: taboo and the censoring of language. Cambridge: Cambridge University Press.

Aristotle. 2000. The Art of Rhetoric. Greek and English. Trans. J. H. Freese. Cambridge, MA: Harvard University Press.

Austin, John L. 2005. How to Do Things With Words. Cambridge, MA: Harvard University Press. Ayto, John (ed.). 2010. Oxford Dictionary of English Idioms. Oxford: Oxford University Press. Barnden, John A. 2017. Irony, pretence and fictively-elaborating hyperbole. In Angeliki Athanasiadou and Herbert L. Colston (eds.), Irony in Language Use and Communication, 145-177. Amsterdam: John Benjamins.

Barnden, John A. 2018. Broadly reflexive relationships, a special type of hyperbole, and implications for metaphor and metonymy. Metaphor \& Symbol 33 (3). 218-234.

Barnden, John A. 2020. Uniting irony. Hyperbole and metaphor in an affect-centred pretencebased framework. In Angeliki Athanasiadou and Herbert L. Colston (eds.), The Diversity of Irony, 15-65. Berlin: De Gruyter Mouton.

Bednarek, Monika. 2019. The multifunctionality of swear/taboo words in television series. In J. Lachlan Mackenzie \& Laura Alba-Juez (eds.), Emotion in Discourse, 29-54. Amsterdam: John Benjamins.

Brewer's Dictionary of Phrase and Fable. 2001. Ed. Adrian Room. London: Cassell.

Buckledee, Steve. 2018. The Language of Brexit: How Britain Talked Its Way Out of the European Union. London: Bloomsbury.

Burgers, Christian, Britta Brugman, Kiki Renardel de Lavalette \& Gerard Steen. 2016. HIP: A Method for Linguistic Hyperbole Identification in Discourse. Metaphor \& Symbol 31 (3). 163-178.

Burgers, Christian, Kiki Renardel de Lavalette \& Gerard Steen (2018). Metaphor, hyperbole, and irony: Uses in isolation and in combination in written discourse. Journal of Pragmatics 127. 71-83.

Carston, Robyn \& Catherine Wearing. 2011. Metaphor, hyperbole and simile: A pragmatic approach. Language and Cognition 3 (2). 283-312.

Carston, Robyn \& Catherine Wearing. 2015. Hyperbolic language and its relation to metaphor and irony. Journal of Pragmatics 79. 79-92.

Charteris-Black, Jonathan. 2019. Metaphors of Brexit: No Cherries on the Cake? Basingstoke: Palgrave Macmillan.

Colston, Herbert L. \& Shauna B. Keller. 1998. You'll never believe this: Irony and hyperbole in expressing surprise. Journal of Psycholinguistic Research 27 (4). 499-513.

Colston, Herbert L. \& Jennifer O’Brien. 2000. Contrast of kind versus contrast of magnitude: The pragmatic accomplishments of irony and hyperbole. Discourse Processes 30 (2). 179-199.

Crespo-Fernández, Eliecer. 2006. The Language of Death: Euphemism and Conceptual Metaphorization in Victorian Obituaries. SKY Journal of Linguistics 19. 101-130.

Dallison, Paul. 2017a. A brief history of having cake and eating it. Politico, 31 August 2017. https://www.politico.eu/article/a-brief-history-of-having-cake-and-eating-it/ (accessed 25 August 2020).

Dallison, Paul. 2017b. Bad Brexit Metaphor club. Politico, 24 October 2017. https://www.politico.eu/article/brexit-bad-metaphor-club-cliches-soundbites/ (accessed 25 August 2020)

Demata, Massimiliano. 2019. 'The referendum result delivered a clear message': Jeremy Corbyn's populist discourse. In Veronika Koller, Susanne Kopf \& Marlene Miglbauer (eds.), Discourses of Brexit, 123-139. London: Routledge. 
Đurović, Tatiana \& Nadezda Silaški. 2018. The end of a long and fraught marriage: Metaphorical images structuring the Brexit discourse. Metaphor and the Social World 8 (1). 25-39.

Gimson, Andrew. 2006. Boris. The Rise of Boris Johnson. London: Simon \& Schuster.

Grice, H. P. 1975. Logic and Conversation. In: Peter Cole \& Jerry L. Morgan (eds.), Syntax and Semantics 3: Speech acts, 41-58. New York: Academic Press.

Halliday, M. A. K. 1978. Language as Social Semiotic. London: Edward Arnold.

Hansson, Sten. 2019. Brexit and blame avoidance: Officeholders' discursive strategies of selfpreservation. In Veronika Koller, Susanne Kopf \& Marlene Miglbauer (eds.), Discourses of Brexit, 191-207. London: Routledge.

Holmes, Janet \& Miriam Meyerhoff. 1999. The Community of Practice: Theories and methodologies. Language in Society 28. 173-183.

Jakobson, Roman. 1960. Closing Statement: Linguistics and Poetics. In Thomas A. Sebeok (ed.). Style in Language, 350-377. Cambridge, MA.: M.I.T. Press.

Kalkhoven, Lieuwe \& Christ'l De Landtsheer. 2016. Politics, it has never been so simple. Complex vs. Simple Rhetoric and the use of hyperbole in political decision-making in the Netherlands. In Peter Bursens, Christ'l De Landtsheer, Luc Braeckmans \& Barbara Segaert (eds.), Complex Political Decision-Making. Leadership, Legitimacy and Communication, 183-202. London: Routledge.

Koller, Veronika, Susanne Kopf \& Marlene Miglbauer (eds.). 2019. Discourses of Brexit. London: Routledge.

Lakoff, George. 1996. Moral Politics: What Conservatives Know That Liberals Don't. Chicago: University of Chicago Press.

Lakoff, George \& Mark Johnson. 1996. Metaphors we live by. Chicago: University of Chicago Press.

Lanham, Richard A. 1991. A Handlist of Rhetorical Terms. Berkeley: University of California Press.

Lausberg, Heinrich. 1984. Elemente der literarischen Rhetorik. Munich: Hueber.

Margulies, Ben. 2019. Understanding Boris Johnson's appeal: performative rebelliousness, impishness and indiscipline. Blogs.lse.ac.uk, 1 August 2019. https://blogs.lse.ac.uk/ politicsandpolicy/the-appeal-of-boris-johnson/ (accessed 1 December 2020)

Musolff, Andreas. 2006. Metaphor Scenarios in Public Discourse. Metaphor and Symbol 21(1). 23-38.

Musolff, Andreas. 2016. Political Metaphor Analysis: Discourse and Scenarios. London: Bloomsbury.

Musolff, Andreas. 2017. Truths, lies and figurative scenarios: Metaphors at the heart of Brexit. Journal of Language and Politics 16 (5). 641-657.

Musolff, Andreas. 2019. Brexit as "having your cake and eating it": the discourse career of a proverb. In Veronika Koller, Susanne Kopf \& Marlene Miglbauer (eds.), Discourses of Brexit, 208-221. London: Routledge.

Norrick, Neil R. 2004. Hyperbole, extreme case formulation. Journal of Pragmatics 36 (9). $1727-1739$.

Oliver, Tim. 2018. Understanding Brexit: A concise introduction. Bristol: Policy Press.

Payne, Sebstian. 2016. Fear, loathing and George Osborne dominate the Brexit campaign. Financial Times, 18 April 2016.

Peña, M. Sandra \& Francisco J. Ruiz de Mendoza. 2017. Construing and Constructing hyperbole. In Angeliki Athanasiadou (ed.), Studies in Figurative Thought and Language, 42-73. Amsterdam: John Benjamins. 
Pesendorfer Dieter. 2020. Brexit and Financial (Dis)Integration: Between Cakeism, Project Fear, and Reality. In (idem): Financial Markets (Dis)Integration in a Post-Brexit EU, 193-252. Cham: Palgrave Macmillan.

Pinker, Steven. 1994. The game of the name. The New York Times, 5 April 1994.

Purnell, Sonia. 2011. Just Boris: Boris Johnson: The Irresistible Rise of a Political Celebrity. London: Aurum Press.

Quintilian. 2001. Institutio oratoria. [Education of the Orator]. Trans. D. A. Russell. 5 vols. Cambridge, MA: Harvard University Press.

Reisigl, Martin \& Ruth Wodak. 2009. The discourse-historical approach (DHA). In Ruth Wodak \& Michael Meyer (eds.), Methods for Critical Discourse Analysis, 87-121. London: Sage.

Rowinsky, Paul. 2017. Evolving Euroscepticisms in the British and Italian Press. Selling the Public Short. Basingstoke: Palgrave.

Shorter Oxford English Dictionary. 1993. Ed. L. Brown. Oxford: Oxford University Press.

Speake, Jennifer. (ed.). 2015. Oxford Dictionary of Proverbs. Oxford: Oxford University Press.

Sperber, Dan \& Deirdre Wilson. 1981. Irony and the use-mention distinction. In Peter Cole (ed.), Radical Pragmatics, 295-318. New York: Academic Press.

Spiering, Menno. 2015. A cultural history of British Euroscepticism. Basingstoke: Palgrave Macmillan.

Wilkinson, P. R. 2008. The Concise Thesaurus of Traditional English Metaphors. London: Routledge.

Wilson, Deirdre \& Dan Sperber. 2012. Explaining irony. In: Deirdre Wilson \& Dan Sperber. Meaning and Relevance, 123-145. Cambridge: Cambridge University Press.

Zappettini, Franco. 2019. The Official Vision for 'Global Britain'. Brexit as rupture and continuity between free trade, liberal internationalism and 'values'. In Veronika Koller, Susanne Kopf \& Marlene Miglbauer (eds.), Discourses of Brexit, 140-154. London: Routledge.

\section{Article history:}

Received: 09 February 2021

Accepted: 1 June 2021

\section{История статьи:}

Дата поступления в редакцию: 09 февраля 2021

Дата принятия к печати: 1 июня 2021

\section{Bionote:}

Andreas MUSOLFF is Professor of Intercultural Communication at the University of East Anglia in Norwich (UK). His research interests focus on Cultural Metaphor Studies, Intercultural and Multicul-tural communication, and Public Discourse Analysis. He has published widely on figurative language use in the public sphere, e.g. the monographs National Conceptualisations of the Body Politic. Cultural Experience and Political Imagination (2021), Political Metaphor Analysis. Discourse and Scenarios (2016), Metaphor, Nation and the Holocaust (2010), Metaphor and Political Discourse (2004), and the co-edited volumes Metaphor and Intercultural Communication (2014), Contesting Europe's Eastern Rim: Cultural Identities in Public Discourse (2010) and Metaphor and Discourse (2009). 


\section{Contact information:}

University of East Anglia

Norwich, UK

e-mail: a.musolff@uea.ac.uk

ORCID: 0000-0001-5635-7517

\section{Сведения об авторе:}

Андреас МУЗОЛФ - профессор, преподает межкультурную коммуникацию в Университете Восточной Англии в Норидже (Великобритания). Сфера его научных интересов - исследование метафоры в культурологическом аспекте, межкультурная и мультикультурная коммуникация, публичный дискурс. Имеет многочисленные публикации, посвященные использованию языковой образности в публичном дискурсе, в том числе монографии National Conceptualisations of the Body Politic. Cultural Experience and Political Imagination (2021), Political Metaphor Analysis. Discourse and Scenarios (2016), Metaphor, Nation and the Holocaust (2010), Metaphor and Political Discourse (2004). Выступал в качестве соредактора коллективных монографий Metaphor and Intercultural Communication (2014), Contesting Europe's Eastern Rim: Cultural Identities in Public Discourse (2010) and Metaphor and Discourse (2009).

\section{Контактная информация:}

University of East Anglia

Norwich, UK

e-mail: a.musolff@uea.ac.uk

ORCID: 0000-0001-5635-7517 